\title{
"Ban the Bomb! Redress the Damage!": The History of the Contentious Politics of Atomic Bomb Sufferers in Japan
}

\author{
Akiko Naono
}

Contrary to its humanist image, Hidankyo, the Japan Confederation of Atomic and Hydrogen Bomb Sufferers Organizations, has engaged in contentious politics against the state for decades. This article traces the little-known history of the Hidankyo movement from the mid-1950s to the early 1980s, introducing how this organization formed in relation to the movement to ban nuclear bombs in the mid-1950s and how it grew into an independent social movement organization with clear policy demands after overcoming an organizational crisis triggered by the Cold War politics of the 1960s. The movement slogan for Hidankyo, "no more hibakusha," did not naturally emerge from the sufferers' experience with the atomic bombings, but was substantiated through their struggles to confront their adversaries, most importantly the Japanese government.

Keywords atomic bomb survivor, peace movement, anti-nuclear movement, Cold War politics, postwar Japan, Japan's nuclear policy

\section{Unknown History of Contentious Politics}

With the adaptation of the Treaty on the Prohibition of Nuclear Weapons in July 2017 and the subsequent awarding of the Nobel Peace Prize to the International Campaign to Abolish Nuclear Weapons (ICAN) in October of the same year, hibakusha, a Japanese term literally meaning "the bombed" but often translated as "atomic bomb survivors," have once again come into the spotlight in talks on antinuclear activism. As evidenced in the remarks made by the members of ICAN, who note that the peace prize is also for the hibakusha, these survivors are recognized as the "public conscience" in nuclear disarmament efforts (United Nations Office for Disarmament Affairs 2018, 12). In fact, their national organization, the Japan Confederation of Atomic and Hydrogen Bomb Sufferers Organizations, known as Hidankyo, has been nominated several times for the 
peace prize for its efforts to "promote the cause of a ban on atomic and hydrogen bombs, by making known their sufferings and struggles" (International Peace Bureau 2015). As the nominating letter by the International Peace Bureau shows, the slogan of Hidankyo's movement, "no more hibakusha," has gained international recognition. However, its sixty-plus year history is not well known, nor is its history of contentious politics against the Japanese state.

Hidankyo, created in the summer of 1956, is the only nationwide social movement organization (SMO) of Japanese hibakusha. Since its inception, Hidankyo has pledged to stand up against atomic bombs so that the suffering experienced by the hibakusha will never be repeated. The principle of "never again," however, should not be taken simply as a humanist message; it is inseparable from the hibakusha's struggles to make the Japanese state redress their suffering. In fact, unlike some nuclear disarmament advocacy groups that focus on public education, Hidankyo's endeavor fits perfectly into the definition of social movements as contentious politics offered by Sydney Tarrow (2011, 9, emphasis in original): "collective challenges, based on common purposes and social solidarities, in sustained interaction with elites, opponents, and authorities."

Compared to its relative visibility in nuclear disarmament discourse, there has been little academic inquiry into Hidankyo's endeavors. There are historical and sociological studies of the Hidankyo movement, albeit in a limited scope, by Japanese scholars such as Ubuki Satoru (1995; 2014), Ishida Tadashi (1986a; 1986b), Hamatani Masaharu (1977), and Naono Akiko (2011; 2015). Historical studies by Tachibana Seiitsu (1996) and James J. Orr (2001) are the only academic studies in English that present the movement's history.

Tachibana introduces the history of Hidankyo quite succinctly and makes the important observation that the hibakusha developed their consciousness to protest both war and atomic bombs through the realization that war brought about the atomic bombings in the first place. Although very brief, Tachibana's study makes an important contribution in English by positioning the Hidankyo movement not simply as an anti-nuclear movement but also as a set of efforts aimed at the "reestablishment of human rights" (Tachibana 1996, 185).

Unlike Tachibana, Orr is critical not only of the Japanese government but also of peace movements in Japan, including the hibakusha movement, because he sees them as part of the "ideology of peace" that helped turn the Japanese people's attention away from Japan's past acts of aggression. Orr presents Hidankyo's main objective as "to obtain better government treatment" or to secure the "privileges equal to those accorded veterans" that come with being "honored for service to the state" (Orr 2001, 171). However, Hidankyo's rationale for demanding compensation from the state differs significantly from the rationales of veterans' groups.

As noted by Orr, many overlook, or are even ignorant of, the fundamental struggle of Hidankyo: to make the Japanese state accept responsibility for 
the atomic bombing damage as a result of its involvement in World War II. Unlike its humanist image, Hidankyo's history is filled with struggles against its adversaries. In fact, Hidankyo had to overcome its adversaries' attempts to split the organization and delegitimize its moral claims.

When it was founded, Hidankyo did not have a firmly fixed set of demands against the state, nor was its collective action necessarily contentious. The organization's demands, furthermore, were not clearly articulated in relation to the organization's objective of "no more hibakusha." It was only through its long struggle to overcome many obstacles that Hidankyo was able to strengthen solidarity among its members, present its fundamental demands clearly, and plead for "no more" with confidence.

By accounting for the little-known history of the Hidankyo movement, this article attempts to show how Hidankyo came to engage in contentious politics against the state. It focuses on how Hidankyo was created in relation to the movement to ban nuclear bombs in the mid-1950s, how it grew as an independent SMO in the early 1970s after managing to overcome an organizational crisis in the 1960s, and how it became increasingly oppositional to the national government throughout the 1970s and early 1980s. While Hidankyo is still active today, this article ends with a discussion of the position paper released in 1984 since it presents Hidankyo's organizational objectives in the most articulate language and has been considered to be the guiding paper for the movement to date.

This article aims to empirically and theoretically analyze the processes through which Hidankyo came to substantiate the slogan "no more hibakusha" by negotiating with and confronting its adversaries. Thus, this article fills a historiographical gap in the literature, especially in English, on hibakusha and peace movements in Japan and presents an alternative account of atomic bomb survivors' struggles for peace. As a historical inquiry, it is based on archival research in the movement's documents, including memoirs of Hidankyo leaders, foundational papers, position papers, minutes of executive committee meetings and general meetings, newsletters, pamphlets, and petition papers.

\section{The Ban-the-Bomb Movement and the Formation of Hidankyo}

The first several years after the atomic bombings were an extremely difficult period for the survivors who became sick from unknown and often fatal illnesses and lived in severe poverty. Although they were in desperate need of public assistance, it was extremely difficult for survivors to organize themselves to collectively demand attention from state authorities during the U.S. occupation, which censored publications that discussed suffering caused by the atomic bombings. Toward the end of the occupation, there were some efforts to organize 
the survivors. Although these efforts were limited in scope, they provided the foundation for a nationwide survivors' movement to emerge in the mid-1950s after a popular movement to ban nuclear bombs was formed in Japan.

In March 1954, the "Lucky Dragon No. 5," a Japanese tuna-fishing vessel, was exposed to radioactive fallout from a U.S. hydrogen bomb test at Bikini Atoll in the Pacific Ocean. Upon its return to Japan, the crew of the Lucky Dragon showed early symptoms of radiation sickness. After a national newspaper broke this news, the Japanese public became aware of the radiological contamination of water and fish. Now aware of the threat of radiation to their food, health, and livelihood, people from all walks of life formed petition movements calling for the prohibition of hydrogen and atomic bomb testing. Regardless of their political and ideological positions, most Japanese supported the ban-the-bomb movement, and more than twenty million signatures, representing close to 30 percent of the total population, were gathered in less than a year after the incident (Hiroshimashi 1984, 123).

In the ban-the-bomb discourse, the Lucky Dragon Incident was positioned as the third Japanese tragedy caused by nuclear bombs. As a result, the collective memory of Hiroshima and Nagasaki came to be firmly nationalized in Japan. However, that sequence of events did not immediately raise public awareness of the sufferers of the two atomic-bombed cities. It was only after the participants of the nationwide movement had the opportunity to listen to the voices of the sufferers in person at the World Conference against Atomic and Hydrogen Bombs, held in Hiroshima in the summer of 1955, that the ban-the-bomb movement turned its attention to the suffering of the survivors and advocated assisting them (Fujiwara 1991, 53-59).

Nevertheless, atomic bomb survivors were greatly encouraged by the overwhelming public support for the ban-the-bomb movement, and they formed their national organization, Hidankyo, on August 10, 1956, during the Second World Conference held in Nagasaki. At their inaugural meeting, Hidankyo declared its intention to "save humanity from its crisis through the lessons learned from our experiences" (Nihon Gensuibaku Higaisha Dantai Kyogi-kai 1956b). Hidankyo also announced its present objectives including pushing for an international agreement to ban atomic and hydrogen bombs and demanding the institutionalization of medical and social assistance measures for the sufferers (Nihon Gensuibaku Higaisha Dantai Kyogi-kai Nihon Hidankyo-shi Henshū Iinkai 2009, 88-89). From its inception, Hidankyo presented what would grow into its "two fundamental demands" - the elimination of nuclear weapons and the enactment of the Hibakusha Relief Law —as its organizational objectives, albeit in relatively unsophisticated language.

Pressured by the popular ban-the-bomb movement and in collaboration with the municipal governments of A-bombed cities and the newly formed Hidankyo, the government enacted the "Atomic Bomb Medical Law" in 1957, 
which aimed to maintain and improve "hibakusha's health with state-sponsored check-ups and medical assistance” (Hibakusha Engo Hōrei Kenkyu-kai 2003, 160). Although this measure was insufficient to alleviate the hibakusha's healthrelated problems or improve their living conditions, it was nonetheless the very first state assistance directed at the atomic bomb sufferers.

While building on the preexisting networks of small groups of survivors and their supporters, such as the Atomic Bomb Victims Association in Hiroshima (formed in August 1952) and the Atomic Bomb Women's Group in Nagasaki (formed in June 1953), sufferers seized "political opportunities" (Tarrow 2011) created by the Lucky Dragon Incident and the subsequent ban-the-bomb movement to organize themselves into a national organization. ${ }^{1}$ The Incident not only helped raise public awareness of the fatal danger of nuclear bombs but also led to positioning Hiroshima and Nagasaki as national symbols of victimization. This shift in perception made it easier and more convincing to frame assistance for the survivors of the two cities as the obligation of the "only atomic-bombed nation." Moreover, due to the increased public sympathies, funds were raised for the survivors to receive health check-ups in several prefectures, such as Nagano, Tokyo, Ehime, and Gunma. These check-ups helped the sufferers to find each other and organize themselves into regional groups. ${ }^{2}$ In other cases, such as in Kanagawa and Kyoto prefectures, sufferers found each other by attending local ban-the-bomb conferences and organized themselves into groups (Ubuki 1995, 531-533). At its inaugural meeting in 1956, Hidankyo was formed of four prefectural organizations in Hiroshima, Nagasaki, Ehime, and Nagano, in addition to individual sufferers from other parts of Japan. With the increasing number of regional groups being formed throughout Japan, Hidankyo would truly become a national confederation. ${ }^{3}$

Public support of the ban-the-bomb movement was the greatest external resource for the atomic bomb sufferers, who, as a group, lacked political and financial resources compared to veterans and repatriates. When the ban-thebomb movement began to turn its energy to ideological battles and lose public support, Hidankyo found itself in a difficult position.

\section{Cold War Politics Playing Out in the Ban-the-Bomb Movement}

As an SMO emerged from the ban-the-bomb movement, Hidankyo was initially a member organization of the Gensuikyo [Japan Council against Atomic and Hydrogen Bombs], the umbrella organization of the ban-the-bomb movement which was formed after the World Conference in 1955. Hidankyo received financial support from Gensuikyo and took part in actions initiated by Gensuikyo, such as lobbying politicians and government officials and sending delegates across Japan and abroad (Nihon Gensuibaku Higaisha Dantai Kyogi-kai 
Nihon Hidankyo-shi Henshū Iin-kai 2009, 75-78). However, Hidankyo ultimately distanced itself from Gensuikyo and withdrew its membership in the mid-1960s.

Around the end of the 1950s and in the early 1960s, Gensuikyo became increasingly progressive and began focusing on issues of nuclear armament in Japan and at U.S. military bases. As the renewal of the Japan-U.S. Treaty of Mutual Cooperation and Security surfaced as a major political issue toward the end of the 1950s, Gensuikyo joined as one of the leading organizations in the alliance to stop renewal. The renewal of the treaty was understood as a means of incorporating the Japanese Self Defense Force into the U.S. nuclear strategy in East Asia and of allowing U.S. forces to be permanently stationed on Japanese soil, thus exposing Japan to the threat of atomic warfare. While opposition to U.S. bases had been expressed since the World Conference in 1955, the U.S.-Japan security treaty became a major political concern for Gensuikyo in the late 1950s (Hiroshima-shi 1984, 193-198). Gensuikyo became more antagonistic to the conservative Liberal Democratic Party (LDP) administration, which advocated for renewing the treaty. As a result, the movement, which initially framed itself as "non-political" and "ideologically neutral" to mobilize a wide spectrum of the population, became explicitly "political" and antagonistic to the LDP-led government.

The LDP had shown support for the World Conference as a way to cater to public opinion, but as the Gensuikyo-led movement began to focus its efforts to oppose the security treaty, the LDP began maneuvering to weaken Gensuikyo's leadership in the movement. A month before the Fifth World Conference was to be held in Hiroshima in 1959, the Hiroshima prefectural council decided to cancel its financial support for the Conference following the initiative of its LDP members (ibid., 245). Subsequently, other prefectural assemblies, such as Niigata and Yamaguchi, also decided to cancel or suspend their financial support to the Conference. At the national level, the National Association of Chairpersons of Prefectural Assemblies adopted a resolution calling on Gensuikyo to act "prudently" (ibid., 247). Despite these conservatives' efforts to thwart it, the World Conference was held in Hiroshima with more than 10,000 participants, twice as many as the previous year. Attempts to disrupt it continued during the Conference: Hiroshima LDP members distributed flyers with a call to "normalize" the Conference, and radical right-wingers physically attacked the participants (ibid., 249-254).

LDP members and other conservative elites continued to position themselves as the conscience of the ban-the-bomb movement and to isolate the leftists from the popular movement. In particular, they attempted to win support from hibakusha by endorsing expanded assistance measures. LDP's Hiroshima prefectural charter formed a special committee to legislate assistance measures for hibakusha in September 1959 in addition to committees to "normalize" the ban-the-bomb movement (Chugoku Shimbun 1959). 
Conservatives' attempts to weaken Gensuikyo's presence in the ban-thebomb movement were furthered by the founding of a new ban-the-bomb organization. In August 1959, the LDP's Hiroshima prefectural charter called for setting up a "new Gensuikyo" (Chugoku Shimbun-sha 1995, 358). While the LDP did not take any further initiative to form a new organization, the Democratic Socialist Party (DSP), which was founded in January 1960 by the right-wing members of the Japan Socialist Party (JSP), and the All-Japan Trade Union Congress (Zenrō Kaigi), which broke from the General Council of Trade Unions of Japan, the JSP's strong support base, formed the National Council for Peace and Against Nuclear Weapons (known as Kakkin Kaigi) in July 1961. The LDP was not a board-member organization of Kakkin Kaigi; however, prominent members of the party, such as Yoshida Shigeru and Kishi Nobusuke, assumed official positions as advisors in Kakkin Kaigi (Shishido 1962, 45). ${ }^{4}$

Kakkin Kaigi denounced Gensuikyo for its "anti-American and procommunist stance" and claimed to be the champion of the humanist approach to peace and the banning of nuclear weapons. As an attempt to position itself as a humanist organization, Kakkin Kaigi called for promoting relief measures for hibakusha (Hiroshima-shi 1984, 272-277).

After the founding of Kakkin Kaigi, more political turmoil was seen in the movement; when the Soviet Union resumed nuclear testing in September 1961, it engendered antagonism between the remaining socialists and communists in Gensuikyo. Ultimately, the movement was split into three camps: conservatives, socialists, and communists.

\section{The Coming of a Crisis in Hidankyo}

Political and ideological disputes in the ban-the-bomb movement were brought home to Hidankyo because it was a member organization of Gensuikyo and because several of its leaders, such as Moritaki Ichiro and Fujii Heiihi in Hiroshima and Kosasa Hachiro in Nagasaki, were active participants of Gensuikyo. ${ }^{5}$ At board meetings in 1959, the positioning of Hidankyo in relation to the "politicized" World Conference was a subject of heated debate. Some feared that Hidankyo would be labeled radical if it engaged in issues of the U.S.-Japan Security Alliance Treaty, and they therefore advocated that Hidankyo concentrate on promoting relief for hibakusha (Nihon Gensuibaku Higaisha Dantai Kyogi-kai 1959a; 1959b).

Disagreements over the positioning of Hidankyo in relation to the leftleaning Gensuikyo almost split the organization. While no consensus had been reached, the Hyogo prefectural member organization decided to withdraw from the Hyogo branch of Gensuikyo in the spring of 1960 (Nihon Gensuibaku Higaisha Dantai Kyogi-kai 1960b). At the seventh general meeting held in August 
1962 , a resolution was jointly proposed by eleven prefectural affiliates, including Hyogo and Öita, suggesting that Hidankyo join Kakkin Kaigi if it remained a member of Gensuikyo; if not, then it should withdraw from Gensuikyo and not be affiliated with any ban-the-bomb organization (Nihon Gensuibaku Higaisha Dantai Kyogi-kai 1962b). Because no consensus was reached, the matter was left to the board meeting.

In early September, the board made a decision that Hidankyo would retain its organizational membership in Gensuikyo (Nihon Gensuibaku Higaisha Dantai Kyogi-kai 1962c). This decision turned out to be unsuccessful in maintaining Hidankyo's organizational unity; a week after the board's decision, the Öita prefectural member organization decided to withdraw not only from the local branch of Gensuikyo but also from Hidankyo. Instead, it joined the newly formed National Federation of Hibakusha (Nihon Gensuibaku Higaisha Dantai Kyogikai Nihon Hidankyo-shi Henshū Iin-kai 2009, 103; Itō 1976, 24). Over the next few years, heated discussions continued regarding whether the organization should maintain its membership in Gensuikyo. At the nineteenth meeting of the executive board of regional representatives held in February 1965, the final decision was made that Hidankyo would keep its organizational unity but not join any particular ban-the-bomb organization (Nihon Gensuibaku Higaisha Dantai Kyogi-kai 1965).

The struggle among competing political camps to win hegemony over the popular ban-the-bomb movement certainly reflected the Cold War politics of the time. It seems that the conservative elites, who considered the security alliance with the United States indispensable to their political dominance, ultimately prevailed: the movement split, Gensuikyo lost its popular support, and the public turned away from the movement. While Hidankyo had barely managed to maintain its organizational unity, the party-line split of the ban-thebomb movement was nevertheless a blow. The crisis was triggered, at least to a certain extent, by conservative forces that attempted to use relief for hibakusha as political leverage to win popular support.

As the only people who have experienced the atomic hell, hibakusha have emerged as the voice of conscience for the ban-the-bomb movement. Therefore, in trying to appeal to the public, it would benefit the conservatives to separate Hidankyo from the influence of Gensuikyo and attract hibakusha to their side. In fact, some Hidankyo leaders were alarmed that conservative forces intended to weaken Gensuikyo by using relief for hibakusha as leverage to organize an alternative ban-the-bomb movement. The conservative forces sought to win hibakusha support while positioning the abolition of atomic bombs as a separate and secondary issue for hibakusha (Nihon Gensuibaku Higaisha Dantai Kyogikai 1959d; 1960a). ${ }^{6}$ Some saw the formation of Kakkin Kaigi precisely as a conservative attempt to reduce the power of the Gensuikyo-affiliated Hidankyo by prioritizing hibakusha relief on its list of organizational objectives. One of 
the more direct attempts to split Hidankyo, as some noted, was the formation of the National Federation of Hibakusha (Zenhikyo) (Nihon Gensuibaku Higaisha Dantai Kyogi-kai 1962a; 1962b).

Zenhikyo was formed in May 1962 as an initiative of conservative politicians such as Nitoguri Tsukasa, a prominent LDP politician and a former chairperson of the Hiroshima City Council. In April 1961, replacing the mayor, he took the post of the president of the Hiroshima City Federation of Hibakusha, formerly the Hiroshima City Atomic Bomb Victims Association, which was a prefecturewide collectivity of local associations of hibakusha throughout Hiroshima (Chugoku Shimbun 1961a). This organization was sponsored by the municipal government. It had been founded in 1957 and aimed primarily to inform and assist hibakusha in their efforts to receive relief under the Medical Law. As such, it was not a hibakusha SMO like Hidankyo. However, reorganization of the City Association into the City Federation was a move to distance hibakusha from the Hidankyo, which was affiliated with the progressive Gensuikyo. The City Federation decided not to cooperate with Gensuikyo's fund-raising campaign in 1961 and accused Gensuikyo of being "politically biased" (Chugoku Shimbun 1961b). The Federation decided not to receive relief funds from Gensuikyo and instead received funds from the newly established Kakkin Kaigi (Chugoku Shimbun 1961c). The City Federation then took the initiative to form Zenhikyo with some hibakusha from Nagasaki and Shimane in the following year (Chugoku Shimbun 1962a). ${ }^{7}$ Zenhikyo further decided that its organizational objectives would not include efforts to ban atomic and hydrogen bombs and instead chose to focus on the promotion of medical care and welfare for hibakusha (Chugoku Shimbun 1962b). Although its membership and influence were limited, the creation of the Zenhikyo forced Hidankyo to take a defensive position.

As an organization composed of sufferers, the group's symbol of unity centered on the atomic bomb experience; as such, it was inevitable that members of Hidankyo varied greatly in terms of their social locations and political and ideological beliefs. As one of the leaders later reflected, simply sharing the experience of having been in Hiroshima or Nagasaki at the time of the bombing provides no guarantee of solidarity (Itō 1975, 193). Despite differences in members' opinions and political beliefs, Hidankyo nevertheless managed to hold itself together as the only nationwide representative organization of atomic bomb sufferers in Japan and never dropped its demand for the government to enact the Hibakusha Relief Law, while the conservative Zenhikyo advocated for only the improvement of existing assistance measures under the Medical Law. Regardless of their positions on the political spectrum, the majority of Hidankyo members considered their suffering to have been caused by the atomic bombings that occurred as a result of war. The logic of calling on the government to compensate sufferers for the damages of the atomic bombings was not yet formulated with concrete evidence in the early 1960s, but by the late 1960s it was fine-tuned 
through efforts to reveal the damage of the bombings and through attempts to incorporate legal and welfare experts' opinions to substantiate the group's claims.

\section{Challenging the Government's War Redress Policy}

Embroiled in the political disputes of the ban-the-bomb movement, the Hidankyo movement stagnated during the first half of the 1960s. However, at the local level, efforts were being made to obtain a fuller picture of the sufferers' plight: some collected and published testimonial accounts, while others conducted small-scale surveys. ${ }^{8}$ These small-scale efforts were compiled by social scientists, including members of the Hidankyo, and laid the groundwork for an important movement document, released in 1966, that would help give the movement direction.

At the time of these efforts to reveal the damage caused by atomic bombings, a historic decision was delivered in December 1963 at the Tokyo District Court. Five atomic bomb sufferers had filed a suit for damages against the Japanese government in 1955 (Matsui 1986, 24, 206-207). The plaintiffs claimed that the use of atomic bombs had violated international law and therefore the U.S. government should take responsibility for the damages, but since the Japanese government had waived claims for damages through the signing of the San Francisco Peace Treaty, the Japanese government should shoulder the responsibility for damages. The court ruled that the dropping of the atomic bombs on Hiroshima and Nagasaki was a violation of international law but denied the plaintiffs' legal rights to receive redress from the Japanese state (ibid., 206-246). Nevertheless, the case was significant in providing legal rationale for hibakusha's demands for state compensation. The court noted that the Japanese government, the defendant in this case, should provide "adequate relief" beyond the existing Medical Law. The court suggested that the government had the responsibility to compensate the hibakusha's plight, which "resulted from a war that the state initiated by its own authority and responsibility" (ibid.).

The verdict led in the following spring to resolutions in both Houses of the National Diet calling for stronger relief to be provided to hibakusha (Sangiin 1964; Shügiin 1964), and the Medical Law was revised the following year (Chugoku Shimbun-sha 1995, 563). Pressured by popular support for the expansion of hibakusha relief, the Ministry of Health and Welfare announced in early 1965 that it would conduct a nationwide survey to investigate the current health and living conditions of the hibakusha so that the government could take appropriate measures on their behalf (Chugoku Shimbun 1965).

Because it was undergoing organizational turmoil, Hidankyo could not immediately seize the opportunity created by the Tokyo District Court verdict. However, efforts were made to unify its members, rebuild solidarity, and shift its energy from being consumed by internal disputes to formulating well-founded 
arguments for its demands to the state. In addition to small-scale local efforts to reveal the damage caused by the atomic bombs, the Specialist Committee was established to draft a theoretically substantiated set of demands that were based on the realities of the sufferers' plight (Itō 1976, 25-26). The committee drafted the "Special Quality of Atomic Bomb Damages and Demand for Hibakusha Relief Law" (popularly called the "Crane Pamphlet" because the paper crane was the pamphlet's front page design), which they hoped would provide an evidencebased and legally founded presentation of Hidankyo's demands.

The Crane Pamphlet outlined the damage in terms of its physical, biological, and social aspects, with a special focus on the "vicious circle of developing atomic-bombing related illness and falling into poverty." As indicated by the title, the report presented in detail the unique aspects of the suffering caused by the atomic bombings by focusing not only on the scale of the bombings but also on the lasting effects of radiation. As such, it attempted to distinguish atomic bombing damage from other war damage, especially the damage caused by incendiary fire bombings. The emphasis placed on the uniqueness of the atomic bombing damage, the Specialist Committee hoped, would provide the rationale for the enactment of the Hibakusha Relief Law, which the government had rejected on the grounds that "preferable treatment" of hibakusha would disrupt the balance in treatment of civilian war sufferers.

Presenting the demands of Hidankyo in the language of concrete policy proposals for the first time, the Crane Pamphlet urged the government to institute a relief law for the atomic bomb sufferers. The proposed act, with thirteen articles, was positioned as a special state measure to "compensate war-related damages of the citizens, for which the state is responsible." Referring to the Tokyo District Court verdict, the pamphlet outlined three reasons the state should compensate the sufferers: (1) the state bears the resultant responsibility to compensate because it was primarily responsible for the war and invited the atomic bombings, which are illegal under international law; (2) the state abandoned the sufferers for twelve years after the bombings; and (3) the state waived its rights to damages from the United States. In addition, the Crane Pamphlet pointed to the state's responsibility to provide medical and welfare assistance for its citizens, guaranteed under the constitution as the citizens' rights to well-being. The relief law for the atomic bomb sufferers, the pamphlet claimed, is a special state measure that is based on the state's responsibility to compensate war victims and to ensure the welfare of its citizens. While emphasizing the state's responsibility to compensate the sufferers by making special reference to the Tokyo District Court verdict several times, the Crane Pamphlet nevertheless positioned the proposed act as part of the state's responsibility for social welfare.

Since its formation in 1956, Hidankyo has demanded the enactment of a "Relief Law for the Sufferers of the Atomic Bombings" abbreviated as the Hibakusha Relief Law. This law is significantly different in substance from the 
Medical Law because it includes comprehensive medical treatment and welfare measures for all sufferers of the atomic bombings, including bereaved families of the victims. Demands were directed to the national government of Japan, not to the U.S. government. This decision was made partly because it was understood as technically impossible to bring those responsible for dropping the atomic bombs to justice, as the Japanese rights to damages had been waived by the San Francisco Peace Treaty. In addition to the legal obstacles, Hidankyo targeted the Japanese government because its members considered their suffering to be caused by war, which was "pursued by the state" (Nihon Gensuibaku Higaisha Dantai Kyogi-kai 1956a). Hidankyo framed the atomic bombing damages as having been caused by the state's act and argued that those damages therefore ought to be remedied by the state. At its early stage, however, the emphasis was placed on the state's responsibility to care for the welfare of the population and not on pinning down its war responsibility. The fact that it named its policy proposal a "relief law" suggests that Hidankyo took the Relief Law for the War Victims and Survivors (hereafter the "Relief Law for the Survivors") as a policy template.

The Relief Law for the Survivors was legislated immediately after the Allied occupation of the Japanese mainland was lifted in April 1952. On the grounds of their having had an affiliation with the state, the Relief Law for the Survivors provided assistance for veterans, civilian military employees, and their bereaved families. The government has insisted that only those who have had a "direct employment relationship with the state" were eligible for measures under the act (Shügiin 1957). Special state assistance, the government argued, was provided for the former employees of the state based on the same principle as the employer's liability (Shügiin 1974). By contrast, civilians who had no affiliation with the state and those from Japan's former colonies, who had been stripped of their Japanese nationality and were therefore not eligible because the Relief Law had a nationality clause, received no assistance (Nihon Bengoshi Rengō-kai 1997, 153164).

State war-redress measures were unfair to the civilians who suffered considerably from the total war, during which the entire population, including the colonies, was mobilized for the war effort. At the same time, the institutionalization of compensatory measures for veterans paved a way for civilian war sufferers to make their demands. Hidankyo took advantage of this opportunity and in presenting its demands followed the model of the Relief Law for the Survivors. However, because the Relief Law for the Survivors was presented by the state as the reward for those who had sacrificed for the nation (Naono 2010), insofar as Hidankyo relied on it as a template for their policy demand, they could not effectively pressure the state to redress the suffering caused by the atomic bombs.

It would be easier, some believed, to obtain state assistance equivalent to that received by veterans by expanding existing government measures. It 
would therefore be wise to pursue lobbying efforts that were consistent with the ideological approach implied in the Relief Law for the Survivors, to drop the accusatory tone, and to make secondary the demand to ban nuclear bombs. Local politicians in Hiroshima and Nagasaki led by LDP council members and groups of bereaved families, especially the parents of deceased junior-highschool students who were mobilized for war efforts, asked the government for condolence money and bereaved family pensions using precisely this line of strategy. They argued that their children died for the country, just like soldiers, and the state ought to acknowledge their service to the nation (Hiroshima-ken Dōingakuto-ra Giseisha no Kai 1975, 86-97).

Through several revisions of the Relief Law for the Survivors, efforts by the bereaved families of deceased students were successful in getting their demands met by the early 1970s (ibid., 92-96). By contrast, Hidankyo continued demanding the enactment of a new state measure despite the conservatives' attempts to destabilize Hidankyo's position by calling for stronger relief for hibakusha through the revision of the existing measures. Hidankyo refused to give in to the political and ideological approach of the Relief Law for the Survivors and managed to remain united under a call for "no more hibakusha" with an implicitly anti-war position. While Hidankyo did not emphasize its slogan of "ban the nuclear bombs" in its collective action during the early 1960s, that slogan would become clearly indispensable to its demand for "no more hibakusha" from the late 1960 s to early 1970 s.

\section{An Oppositional Turn against the State}

Hidankyo became more active in pressuring the national government to institutionalize compensatory measures for atomic bomb sufferers from the late 1960s to early 1970s. While the intellectual leadership of Hidankyo, which mostly comprised liberal professors as well as some labor activists, played some role in its strategic direction, it was largely the government's failure to ease the suffering of the atomic bomb sufferers, combined with its nuclear and security-related policies, that enraged members of Hidankyo and helped them unite under a more contentious stance against the government.

The Ministry of Health and Welfare conducted the first nationwide survey of hibakusha in late 1965 to provide a basis for more appropriate relief measures. The tentative results of the survey findings announced in November 1967 showed that more than a few hibakusha still suffered from physical damage, such as keloid, and had poor living conditions. However, it was concluded that there was no significant difference overall in the health and living conditions of hibakusha and other Japanese, and the survey found no apparent negative influence of the atomic bombings on the hibakusha population as a whole (Sumiya 1968, 113- 
114). This report enraged many hibakusha and Hidankyo immediately protested against the Ministry (Nihon Gensuibaku Higaisha Dantai Kyogi-kai Nihon Hidankyo-shi Henshū Iin-kai 2009, 111-112).

Based on the survey findings, the Special Law for Hibakusha was enacted the following spring. This law was a product of the political developments since the Tokyo Regional Court verdict in 1963 and of the increasing public support for more relief for hibakusha. However, it targeted only hibakusha with special conditions, such as those suffering as a result of the bombings who were identified in the survey, and therefore was far from meeting Hidankyo's demands for comprehensive relief measures for all sufferers (Sumiya 1968, 113). The Special Law was positioned as a special welfare measure, unlike the Relief Law for the Survivors, which was considered a compensatory measure (Hibakusha Engo Hōrei Kenkyu-kai 2003, 170). The characterization of the Special Law and the government refusal to provide hibakusha with state compensation was consistent with the government's position to not compensate civilian war victims.

While recognizing the Special Law as something of an achievement, Hidankyo accused the government of straw-manning the issue and renewed its commitment to promote the enactment of the Hibakusha Relief Law. At its twelfth general meeting held in August 1968, Hidankyo adopted a resolution criticizing the government for neglecting its demands while giving compensation to a limited group of war suffers, such as veterans, civilian military employees, their bereaved, and repatriates (Nihon Gensuibaku Higaisha Dantai Kyogi-kai 1968). In the campaign plans adopted for the following year, Hidankyo connected the government's refusal to admit its responsibility to provide compensation for atomic bombing damages to its underestimation of the damages, with a special note on the conclusion of the 1965 hibakusha survey report. Furthermore, it condemned, in a strong tone, the Japanese government for promoting security policy that relied on nuclear weapons (ibid.).

From the mid- to late-1960s, the conservative LDP administration moved to rely more heavily on U.S. nuclear security. The administration allowed U.S. nuclear submarines to call at Japanese ports several times beginning in 1964. In January 1968, the U.S. nuclear aircraft carrier Enterprise ported at Sasebo, only $50 \mathrm{~km}$ away from the city of Nagasaki, to take part in the Vietnam War (Chugoku Shimbun-sha 1995, 660). These events alarmed many, especially leftist political parties and student and peace activists who were concerned Japan would be armed with U.S. nuclear weapons and contribute to the intensification of the Vietnam War. Faced with strong opposition to the port calls by U.S. warships, high-ranking LDP politicians, including the prime minister, urged resolution of the "nuclear allergy" of the Japanese public (Arase and Okayasu 1968).

In response to these political developments, Hidankyo severely criticized the Japanese government's attitude. At the general meeting held in the summer of 1968, Hidankyo accused the government of underestimating the aftereffects of 
radiation on hibakusha's health:

Denial of the real damage caused by nuclear weapons is linked to [the Japanese government's] attempts to resolve the 'nuclear allergy.' [The government] abandoned hibakusha for twelve years while following the nuclear offender, never conducted a comprehensive damage survey, closed its door to save hibakusha who suffered from illness and poverty by denying to attribute their illness to the effects of atomic bombings. These acts [of the government] are consistent with [its] denial of radioactive contamination [caused by] and the introduction of nuclear weapons [by the United States] (Nihon Gensuibaku Higaisha Dantai Kyogi-kai 1968).

Hidankyo expanded its scope of actions after the enactment of the Special Law so that a state compensatory measure, not merely a welfare measure, would be institutionalized. Hidankyo representatives joined sympathetic scholars who were voicing their opinions in favor of the Hibakusha Relief Law at the public hearings held by the Committee on Social and Labor Affairs of the House of Representatives in July 1969 (Nihon Gensuibaku Higaisha Dantai Kyogi-kai Nihon Hidankyo-shi Henshū Iin-kai 2009, 114). Hidankyo engaged in a series of lobbying efforts and contentious actions from late 1969 to early 1970, such as meeting with members of the Diet and conducting sit-ins in front of memorials for the sufferers of the atomic bombings in Tokyo. One of the fruits of this series of actions was the formation of a committee within the LDP focused on issues concerning hibakusha in November 1970 (ibid., 114-115, 123).

In 1971, Prime Minister Satō Eisaku attended the peace memorial ceremony held in Hiroshima on the anniversary of the bombing, making him the first prime minister to do so. While pledging to work for peace, the prime minister bluntly ruled out the possibility of instituting the Hibakusha Relief Law that Hidankyo had demanded (Chugoku Shimbun 1971). This decision outraged many hibakusha, and Hidankyo organized a large-scale protest in December in the capital city with approximately 1,000 participants from across Japan demanding the enactment of the relief law and the return of a nuclear-free Okinawa (Nihon Gensuibaku Higaisha Dantai Kyogi-kai Nihon Hidankyo-shi Henshū Iin-kai 2009, 124).

At the fifteenth general meeting held in 1971, Hidankyo announced the "Basic Demands of the Atomic Sufferers." Building on the thirteen policy demands outlined in the Crane Pamphlet, Hidankyo solicited opinions from regional organizations across Japan. With the input of the Specialists Committee, twenty-six demands were listed and adopted at the general meeting (ibid., 121). In addition to the state responsibilities for compensation outlined in the Crane Pamphlet, the Hibakusha Relief Law was positioned as a pledge from the state, as the world's only A-bombed nation, to its citizens never to create another hibakusha. As such, it had implications for Japan's nuclear policy (Nihon Gensuibaku Higaisha Dantai Kyogi-kai 1971). Making an explicit reference 
to state security policy, Hidankyo more clearly articulated the connection between its demands for compensation and its call to ban nuclear weapons. In the following year, Hidankyo strongly upheld its claims against not only nuclear bombs but also war in general (Nihon Gensuibaku Higaisha Dantai Kyogi-kai 1973).

Building on the twenty-six demand items, Hidankyo announced the "Essential Demands Outlined in the Relief Law for Sufferers of the Atomic Bombings" (abbreviated as "Essential Demands") in March 1973. At the time of its lobbying efforts in the summer of 1972, the Vice President of the LDP remarked that members of the Diet, not the government, should initiate a proposal on the Hibakusha Relief Law. Instead of waiting for Diet members to draft the law, Hidankyo took the initiative and presented fourteen policy items as its "Essential Demands" in April 1973 (Nihon Gensuibaku Higaisha Dantai Kyogi-kai Nihon Hidankyo-shi Henshū Iin-kai 2009, 127-128). This list included not only comprehensive medical care and welfare measures for hibakusha but also condolence money and pensions for the bereaved families.

Presenting concrete policy proposals, Hidankyo approached both the ruling and opposition parties to support its proposal and pressured each party to draft its own bill. While the ruling LDP did not present its legislative proposal, four opposition parties, Socialist, Communist, Democratic Socialist, and Kōmeitō, each announced their own proposals (ibid., 129, 133). Hidankyo encouraged the four parties to jointly submit a bill, and although they proposed the Hibakusha Relief bill to the National Diet in March 1974, that bill died due to the LDP's opposition (ibid., 135-136, 139-142).

Along with its lobbying efforts, Hidankyo actively engaged in contentious politics. To intensify its efforts towards the enactment of the Hibakusha Relief Law based on the "Essential Demands," Hidankyo planned "major actions" in 1973 and decided to organize a sit-in at the Ministry of Health and Welfare. On the first day of the planned actions in November, Hidankyo sent delegates to the Ministry, but the ministry officials turned their back to Hidankyo's demands. With this negative response, Hidankyo members set up tents in front of the Ministry buildings under rainy weather. This ended after five days of overnight sit-ins with more than 3,000 participants, an unprecedented action by an SMO in Japan (Nihon Gensuibaku Higaisha Dantai Kyogi-kai 1986, 10). A series of highly visible activities successfully won support from opposition parties for legislative efforts and a positive response from the Minister of Health and Welfare (ibid.). Moreover, by undertaking a series of physically straining but emotionally charged activities, participating hibakusha from all parts of Japan strengthened solidarity and became conscious of their shared identity as sufferers of the atomic bombings (Saitō 1986, 94-106). 


\section{The Endurance Doctrine and the Sufferers' Fundamental Demands}

Hidankyo was increasingly active in the late 1970s. It opened a central counseling office in 1976, organized the International NGO Symposium on the Damage and Aftereffects of the Atomic Bombings of Hiroshima and Nagasaki in 1977, and sent a special delegation of forty-one members to the first United Nations Special Session on Disarmament held in New York in 1978 (Nihon Gensuibaku Higaisha Dantai Kyogi-kai Nihon Hidankyo-shi Henshū Iin-kai 2009, 147-148, 159-163, 165-168). Furthermore, Hidankyo started a new campaign to collect 20 million signatures to demand the enactment of the Hibakusha Relief Law in November 1978 (ibid., 172-175). It was in this context of intensification of the movement's activities that a government-appointed committee overtly rejected its demand in late 1980.

The "Committee to Discuss the Basic Issues of the Policy Regarding the Atomic Bomb Survivors" (abbreviated as "Committee to Discuss the Basic Issues") was established in 1979 in direct response to a Supreme Court verdict on a case filed by Korean hibakusha Son Jin-du (Naono 2010). ${ }^{10}$ The Supreme Court verdict was significant because it acknowledged Japanese state responsibility for Mr. Son's sickness, which the Court considered as having resulted from the war-an act of the state. Moreover, the Supreme Court rejected the long-held government position that classified relief measures for hibakusha solely as social welfare programs and suggested that the Medical Law embodied a spirit of state compensation (Hibakusha Engo Hōrei Kenkyu-kai 2003, 895-899).

The verdict pressured the national government to reconsider its policy toward hibakusha. Subsequently, in 1979, the Minister of Health and Welfare appointed seven specialists to examine existing state measures for hibakusha. The final report of this seven-member committee, announced on December 11, 1980, presented legally bounded arguments because it was directed to offset the influence of Mr. Son's case. Directly referring to the Supreme Court verdict, the report acknowledged the laws regarding hibakusha as "a compensatory measure in a broad sense, based on resultant responsibility of the state" (ibid., 890-891). The report emphasized, however, that the responsibility of the state extends only to hibakusha's unique health problems, which are attributable to the aftereffects of radiation (ibid.). Having contained state responsibility for compensating hibakusha for their radiation sickness, the report successfully avoided attributing any legal accountability of the state to meet hibakusha's demand. It thus prevented rights to state compensation from being extended to other war victims by noting hibakusha's unique vulnerability to radiation-caused illness (Naono 2011, 218222).

On the day of its announcement, Hidankyo issued a statement that condemned the committee report for "trampling hibakusha's sincere wish" and for presenting a "horrifying justification of war" (Nihon Gensuibaku Higaisha Dantai Kyogi- 
kai 1980). Most enraging for hibakusha was the report's blatant statement of the "endurance doctrine": "In war, a state of emergency, where the fate of the nation is at stake, all members of the nation are obligated to equally accept and endure some loss in forms of life, body, and assets resulting from war as its general price" (Hibakusha Engo Hōrei Kenkyu-kai 2003, 890). It was in response to this doctrine that Hidankyo appealed to the public to recognize the legitimacy of its demands by alluding to the spirit of the Japanese Constitution, which renounces war.

Not unlike the oppositional turn toward the government in the late 1960s to early 1970s, anger triggered by the government's actions greatly helped to fuel the movement in the 1980s. "Can't endure the suffering caused by the atomic bombs" was a slogan that emerged in response to the committee report (Nihon Gensuibaku Higaisha Dantai Kyogi-kai 2009, 188-190). Hidankyo conducted nationwide surveys and substantiated its claim of why such suffering cannot and should not be tolerated by anyone. The product of these efforts cumulated in the historic document, "No More Hibakusha: Fundamental Demands of the Atomic Bomb Sufferers" (hereafter the "Fundamental Demands") in 1984.

Hidankyo used its two fundamental demands, namely to "ban nuclear weapons and enact the Hibakusha Relief Law," to achieve its wish to never create another hibakusha. ${ }^{11}$ In a morally charged tone, the document presented Hidankyo's demands as relevant to humanity: "Building a fortress to prevent humankind from ever repeating this tragedy-we consider this our mission imposed by history on those who survived the atomic bombings." Moreover, it framed the Hibakusha Relief Law as a means of preventing the recurrence of their suffering and made the Law relevant to the citizens of Japan. Claiming that "compensation for the damage is the first step against similar damage," the Fundamental Demands maintained that the legislation of the Hibakusha Relief Law would serve as a "proclamation by the state that it would never create hibakusha" and would help establish citizens' "right to reject nuclear war and its destruction."

The reasoning for demanding redress from the state was fine-tuned in the Fundamental Demands. At the initial stage of the movement, the state was held responsible for providing assistance to its citizens in the spirit of the welfare state outlined in the Constitution. In the late 1960s and early 1970s, as outlined in the Crane Pamphlet and the Essential Demands, Hidankyo emphasized the resultant responsibility of the state to compensate the sufferers for the damage. Increasingly, in the late 1970s, Hidankyo was clearer in its reasoning for targeting the state's war responsibility, but the decisive move was made by the report issued by the Committee to Discuss the Basic Issues, which bluntly told the atomic bomb sufferers to accept and endure their plight. It was in its efforts to refute the logic presented by the committee that Hidankyo came to regard compensation for atomic bombing damages as a way for the Japanese state to take responsibility 
for the war and to make a commitment never to create another hibakusha.

\section{Historical Implications of the Hidankyo Movement}

Hidankyo's claims and pleas have found resonance among many Japanese, despite the group's sometimes forceful demands and oppositional stance against the state, partly because the collective memory of the atomic bombings in Japan, the memory that positions Japanese as the victims of war, has helped incite a sense of fraternity. Because public support has been the key external resource for Hidankyo since the beginning, the group tended to use language that could induce a sense of comradeship among the Japanese public or a sense of popular nationalism directed against the state to win the public's endorsement. ${ }^{12}$ As a result, Hidankyo did not actively take up the issue of overseas hibakusha, particularly on the Korean Peninsula, until the 1990s. However, it is misleading to accuse Hidankyo of having a low regard for Japan's colonial past or of simply being consumed by "victim consciousness," as some peace activists and leftleaning intellectuals do. As this article has shown, Hidankyo has struggled to challenge the government's position that war-related loss ought to be endured, and it never gave up demanding redress for the suffering due to the atomic bombings. In so doing, Hidankyo has pressured the Japanese government to admit its war responsibility and atone for the suffering that citizens have been forced to endure. In this sense, Hidankyo's long struggle should be valued, as Tachibana $(1996,186)$ suggests, as a call to turn Japan's political culture in the direction of greater democracy and justice (also see Ishida 1986a; 1986b).

To this day, the Japanese government has never responded positively to Hidankyo's two fundamental demands to ban the nuclear weapons and enact the Hibakusha Relief Law. Instead, the government has insisted on providing no compensation so that relief measures for hibakusha cannot be a precedent for other civilian war victims, in Japan and abroad, to make demands for redress (Naono 2015, 63, 239-240). Nor has the government changed the security policy that relies heavily on U.S. nuclear arms; in fact, the current Abe administration has moved to rely more heavily on the U.S. "nuclear umbrella" and supports the Trump administration's move to develop "usable" nuclear weapons.

In a less optimistic political environment towards the idea of never creating another hibakusha, Hidankyo's endeavor continues; it demands the government compensate for the atomic bombing damages and change its security policy, and calls for the international community to ban nuclear weapons. However, as the hibakusha population has aged, more than a few Hidankyo-affiliated local groups and prefectural organizations of sufferers have been dissolved. It is therefore left in our hands to decide which path to take: one with the possibility of creating another hibakusha or the one for which Hidankyo has paved the way. 


\section{Notes}

1. The concept of "political opportunity" in the social movement literature emphasizes the "resources external to the group" (Tarrow 2011, 33).

2. In Nagano, for example, twenty-eight sufferers received health checks and formed the Nagano Prefectural Atomic and Hydrogen Bomb Sufferers' Organization with six more sufferers in 1956 (Ubuki 1995, 553).

3. By 1966, its membership grew to forty-two prefectural affiliates, and all remaining five prefectural organizations were formed and affiliated to Hidankyo by 1985 (Nihon Gensuibaku Higaisha Dantai Kyogi-kai Nihon Hidankyo-shi Henshū Iin-kai 2009, 100, 374-375).

4. Board-member organizations included right-wing and LDP supporter groups, such as Nihon Kensei kai, Fraternity Youth Comrade Association, and Association of Shinto Shrines (Kakuheiki Kinshi Heiwa Kensetsu Kokumin Kaigi 1961, 15). Kakkin Kaigi was presented as an LDP-affiliated organization in newspaper coverage (Asahi Shimbun 1970; Yomiuri Shimbun 1966).

5. Moritaki was a Hiroshima University professor of philosophy, and Fujii was a local welfare commissioner and a prominent member of the Social Welfare Council, whereas Kosasa was an independent Nagasaki City council member.

6. The LDP suggested they would support the relief law for hibakusha if Hidankyo cut ties with the Gensuikyo (Nihon Gensuibaku Higaisha Dantai Kyogi-kai 1959c).

7. Nitoguri was appointed as the president of the Zenhikyo.

8. The Hyogo prefectural organization published its collection of testimonies in 1962, one of the earliest such attempts, and the Shizuoka, Iwate, and Nagano organizations also published the results of surveys conducted in their respective areas.

9. It also included demands for non-Japanese hibakusha to receive equal rights for compensation.

10. Mr. Son, a survivor of Hiroshima, entered Japan "illegally" to receive medical treatment for his radiation-related sickness. His condition deteriorated after being hospitalized, and Mr. Son applied for a hibakusha health certificate, an official document that would recognize him as a hibakusha and make him eligible for medical care under the Medical Law. However, he was denied the classification. Attempting to overturn the government's decision, Mr. Son filed a lawsuit in 1972 and won a landmark victory at the Supreme Court in 1978 (Nakajima 1998).

11. The demand to eliminate nuclear weapons was directed at the governments of nuclear powers. In addition, Hidankyo demanded "a formal apology" from the United States for being the only country to have used atomic bombs and called on the United States to take initiatives to eliminate all nuclear weapons.

12. When Hidankyo became more oppositional to the state in the 1970s and 1980s, it often referred to its campaigns as a "national movement" and to the public as the "people of Japan." 


\section{References}

Arase, Yutaka, and Shigehiro Okayasu. 1968. “'Kaku Arerugī’ to 'Ampo Kōgai': Shimboru Sōsa-1968” ['Nuclear Allergy' and 'Security Pollution': Manipulation of Symbols in 1968]. Sekai 274: 73-84.

Asahi Shimbun. 1970. "Gensuikin 3 Taikai no Shōten” [Focus of the Three Ban-the-Bomb Conferences]. July 30.

Chugoku Shimbun. 1959. "Hibakusha Engo Rippō nado San Tokubetsu-i Moukeru" [Establishing Three Special Committees, including the One to Legislate Assistance Measures for Hibakusha]. September 5.

Chugoku Shimbun. 1961a. "Kaichō ni Nitoguri Shigi, Hiroshima-shi Gembaku Hibakushakyo" [Appointing City Council Nitoguri as the President of the Hiroshima City Federation of Hibakusha]. April 11.

Chugoku Shimbun. 1961b. "Gensuikyo no Seijiteki Henkō wo Hihan" [Criticizing Gensuikyo's Political Biasness]. June 28.

Chugoku Shimbun. 1961c. "Hinkon Setai e Sen-yen ate, Daini Gensuikyo no Kampa" [One Thousand Yen Each for the Impoverished Households, Relief Funds from the Second Gensuikyo]. September 30.

Chugoku Shimbun. 1962a. "Kyō Hiroshima Nagasaki Hibakusha Taikai" [Hiroshima Nagasaki Hibakusha Conference to be Held Today]. May 22.

Chugoku Shimbun. 1962b. "Zenkoku e Sanka Yobikake, Hibakusha-kyo Kaisoku wo Tsukuri" [Calling Out Nationally to Join, City Federation of Hibakusha, Drafting the Organizational Objectives]. November 10.

Chugoku Shimbun. 1965. "Zenkoku no Hibakusha Chōsa, Rainendo Sōsō kara” [National Survey of Hibakusha to be Conducted in Early Next Fiscal Year]. January 10.

Chugoku Shimbun. 1971. "Shin no Heiwa Mezasu Shushō Aisatsu" [Perusing Real Peace, the Message by the Prime Minister]. August 6, Evening Edition.

Chugoku Shimbun-sha, ed. 1995. Nenpyo Hiroshima: Kakujidai 50-nen no Kiroku [Chronicle Hiroshima: 50 Years of the Nuclear Age]. Hiroshima: Chugoku Shimbun-sha.

Fujiwara, Osamu. 1991. Gensuibaku Kinshi Undō no Seiritsu [Formation of the Movement to Ban the Atomic and Hydrogen Bombs]. Tokyo: Meijigakuin Kokusai Kenkyu-sho.

Hamatani, Masaharu. 1977. "Gembaku Higaisha Undō to Jittai Chōsa” [Atomic Bomb Sufferers' Movement and Field Survey]. Hitotsubashi Ronsō 77 (2): 208-224.

Hibakusha Engo Hōrei Kenkyu-kai, ed. 2003. Gembaku Hibakusha Kankei Hōrei Tsūchi Shī [Statu Book related to the Atomic Bombing Hibakusha].Tokyo: Gyosei.

Hiroshima-ken Dōingakuto-ra Giseisha no Kai. 1975. Sengo 30 nen no Ayumi [The History of 30 Years after the War]. Hiroshima: Hiroshima Kenritsu Douingakutora Giseisha no Kai.

Hiroshima-shi, ed. 1984. Hiroshima Shin-shi: Rekishi-hen [A New History of Hiroshima: City's History Edition]. Hiroshima: Hiroshima-shi.

International Peace Bureau. 2015. "Nobel Peace Nomination.” January 30.

Ishida, Tadashi. 1986a. Gembaku Higaisha Engo Hō: Han Gembaku Ronshū 2 [Relief Law for the Atomic Bomb Sufferers: Collected Essays on Thoughts against the Atomic Bombings, vol. 2]. Tokyo: Mirai-sha.

Ishida, Tadashi. 1986b. Gembaku Taiken no Shisō ka: Han Gembaku Ronshū 1 [Turning the Atomic Bomb Experience into a System of Thought: Collected Essays on Thoughts 
against the Atomic Bombings, vol. 1]. Tokyo: Mirai-sha.

Itō, Takeshi. 1975. Hibaku no Shisō to Undo [Thoughts and Movements of the AtomBombed]. Tokyo: Shin hyō-ron.

Itō, Takeshi. 1976. "Nihon Hibakusha Undō no 30-nen" [30 Years of the Japanese Hibakusha’s Movement]. In Hiroshima Nagasaki 30 Nen no Shōgen, Ge [Hiroshima Nagasaki Testimonies of 30 Year, vol. 2], ed. Hiroshima Nagasaki no Shōgen no Kai, 11-30. Tokyo: Mirai-sha.

Kakuheiki Kinshi Heiwa Kensetsu Kokumin Kaigi. 1961. "Kakkin Kaigi no Kongo no Undō" [Movement Plans of Kakkin Kaigi].

Matsui, Yasuhiro. 1986. Gembaku Saiban: Kakuheiki Haizetsu to Hibakusha Engo no Hōri [Trial of the Atomic Bombings: Legal Theory on the Abolishment of Nuclear Weapons and Relief for Hibakusha]. Tokyo: Shin-Nihon Shuppan-sha.

Nakajima Tatsumi. 1998. Chōsenjin Hibakusha Son Jindo Saiban no Kiroku [Report on the Court Case of Korean Hibakusha Son Jin-do]. Tokyo: Zaikan Hibakusha Mondai Shimin Kaigi.

Naono, Akiko. 2010. "Producing Sacrificial Subjects for the Nation: Japan's War-Related Redress Policy and the 'Endurance Doctrine." In Toward a Sociology of Trace, eds. Herman Gray and Macarena Gomez-Barris, 109-134. Minnesota: University of Minnesota Press.

Naono, Akiko. 2011. Hibaku to Hoshō [Exposures to Radiation and Issues of Compensations]. Tokyo: Heibon-sha.

Naono, Akiko. 2015. Gembaku Taiken to Sengo Nihon [Atomic Bomb Experience and Postwar Japan]. Tokyo: Iwanami Shoten.

Nihon Bengoshi Rengō-kai ed. 1997. Nihon no Sengo Hoshō [Japan’s Postwar Redress]. Tokyo: Akashi Shoten.

Nihon Gensuibaku Higaisha Dantai Kyogi-kai. 1956a. "Gembaku Higaisha Engohō-an” [Outline of the Relief Law for the Sufferers of the Atomic Bombings].

Nihon Gensuibaku Higaisha Dantai Kyogi-kai. 1956b. "Sekai e no Aisatsu" [Message to the World].

Nihon Gensuibaku Higaisha Dantai Kyogi-kai. 1959a. "Hidankyo Renraku” [Hidankyo Correspondences]. No. 12, May 10.

Nihon Gensuibaku Higaisha Dantai Kyogi-kai. 1959b. "Hidankyo Renraku” [Hidankyo Correspondences]. No. 14, July 20.

Nihon Gensuibaku Higaisha Dantai Kyogi-kai. 1959c. "Hidankyo Renraku” [Hidankyo Correspondences]. No. 16, October 1.

Nihon Gensuibaku Higaisha Dantai Kyogi-kai. 1959d. "Hidankyo Renraku” [Hidankyo Correspondences]. No. 17, November 15.

Nihon Gensuibaku Higaisha Dantai Kyogi-kai. 1960a. "Hidankyo Renraku” [Hidankyo Correspondences]. No. 23, March 10.

Nihon Gensuibaku Higaisha Dantai Kyogi-kai. 1960b. "Hidankyo Renraku” [Hidankyo Correspondences]. No. 26, June 1.

Nihon Gensuibaku Higaisha Dantai Kyogi-kai. 1962a. "Hidankyo Renraku” [Hidankyo Correspondences]. No. 50, June 25.

Nihon Gensuibaku Higaisha Dantai Kyogi-kai. 1962b. "Hidankyo Renraku” [Hidankyo Correspondences]. No. 52, September 1.

Nihon Gensuibaku Higaisha Dantai Kyogi-kai. 1962c. "Hidankyo Renraku” [Hidankyo 
Correspondences]. No. 53, October 1.

Nihon Gensuibaku Higaisha Dantai Kyogi-kai. 1965. “Hidankyo Renraku” [Hidankyo Correspondences]. No. 71, March 20.

Nihon Gensuibaku Higaisha Dantai Kyogi-kai. 1968. "Hidankyo Renraku” [Hidankyo Correspondences]. No. 78, October 15.

Nihon Gensuibaku Higaisha Dantai Kyogi-kai. 1971. "Hidankyo Renraku” [Hidankyo Correspondences]. No. 81, October 25.

Nihon Gensuibaku Higaisha Dantai Kyogi-kai. 1973. "Hidankyo Renraku” [Hidankyo Correspondences]. No. 82, February 20.

Nihon Gensuibaku Higaisha Dantai Kyogi-kai. 1980. "Kihonkon Tōshin ni tsuite no Kenkai" [Response to the Report of the Committee to Discuss the Basic Issues]. December 11.

Nihon Gensuibaku Higaisha Dantai Kyogi-kai. 1986. "Nihon Hidankyo 30-nen no Ayumi” [30 Year History of the Nihon Hidankyo].

Nihon Gensuibaku Higaisha Dantai Kyogi-kai Nihon Hidankyo-shi Henshū Iin-kai. 2009. Futatabi Hibakusha wo Tsukuru na: Nihon Hidankyo 50-nen Shi [Don't Make Any More Hibakusha - 50 Years of the Nihon Hidankyo]. Tokyo: Akebi Shobō.

Orr, James J. 2001. The Victim as Hero: Ideologies of Peace and National Identity in Postwar Japan. Honolulu: University of Hawai'i Press.

Saitō, Yoshio. 1986. Watashi no Hibakusha Undō [My Life in the Hibakusha Movement]. Tokyo: Shin-nihon Shuppan-sha.

Sangiin. 1964. Sangiin Kaigi-roku [Record of the Plenary Session, House of Councils]. No. 13 (March 27): 8-11.

Shishido Takekazu. 1962. "Daini Gensuikyo wa Heiwa Dantai ka?" [Is the Second Gensuikyo a Peace Organization?]. Gekkan Rōdōo Mondai 44: 44-47.

Shūgiin. 1957. Shügiin Honkaigi-roku [Record of the Plenary Session, House of Representatives]. No. 6 (February 6): 7.

Shūgiin. 1964. Shügiin Honkaigi-roku [Record of the Plenary Session, House of Representatives]. No. 21 (April 3): 1-3.

Shūgiin. 1974. Shūgiin Shakai Rōdō Iinkai-roku [Committee on Social and Labor Affairs, House of Representatives]. No. 21 (April 25): 14.

Sumiya, Mikio. 1968. "Hibaku Mondai no Genten to Genjitsu" [The Origin and Realities of Issues related to the Effects of Atomic Bombings]. Sekai 273: 109-117.

Tachibana, Seiitsu. 1996. “The Quest for a Peace Culture: The A-bomb Survivors' Long Struggle and the New Movement for Redressing Foreign Victims of Japan's War." In Hiroshima in History and Memory, ed. Michael J. Hogan, 168-186. Cambridge: Cambridge University Press.

Tarrow, Sydney G. 2011. Power in Movement: Social Movements and Contentious Politics. Cambridge, Cambridge University Press.

Ubuki, Satoru. 1995. "Nihon Gensuibaku Higaisha Dantai Kyōgi kai no Kessei" [Formation of the Japan Confederation of Atomic and Hydrogen Bomb Sufferers' Organizations]. In Nihon Shakai no Shiteki Kōzō [Japanese Society's Historical Structure], ed. Asao Naohiro Kyojyu Taikan Kinen-kai, 525-544. Kyoto: Shibunkaku Shuppan.

Ubuki, Satoru. 2014. Hiroshima Sengo-shi: Hibaku Taiken wa Dou Uketomerarete Kitaka [Hiroshima's Postwar History: How the Atomic Bombing Experience Has Been Received]. Tokyo: Iwanami Shoten. 
United Nations Office for Disarmament Affairs. 2018. "Treaty on the Prohibition of Nuclear Weapons: Signature and Ratification."

Yomiuri Shimbun. 1966. "Shasetsu: 'Kokumin Fuzai' no Gensuikin Undō” [Editorial: Banthe-Bomb Movement without Public Support]. August 2.

\begin{abstract}
Akiko Naono (Naono is the family name) received a Ph.D. in sociology from University of California, Santa Cruz in 2002. After completing a postdoctoral fellowship from the Research Fellowship for Young Scientists, Japan Society for the Promotion of Science, from 2003 to 2005, she taught sociology and cultural studies as an Associate Professor at the Graduate School of Social and Cultural Studies, Kyushu University, from 2005 to 2016. She has been with the Hiroshima Peace Institute, Hiroshima City University, since 2016.
\end{abstract}

Submitted: August 7, 2018; Revised: September 18, 2018; Accepted: October 4, 2018 